\title{
Interleukin-17 Receptor B
}

National Cancer Institute

\section{Source}

National Cancer Institute. Interleukin-17 Receptor B. NCI Thesaurus. Code C97970.

Interleukin-17 receptor B (502 aa, $\sim 56 \mathrm{kDa}$ ) is encoded by the human IL17RB gene. This protein plays a role in both cytokine binding and interleukin-mediated signaling. 